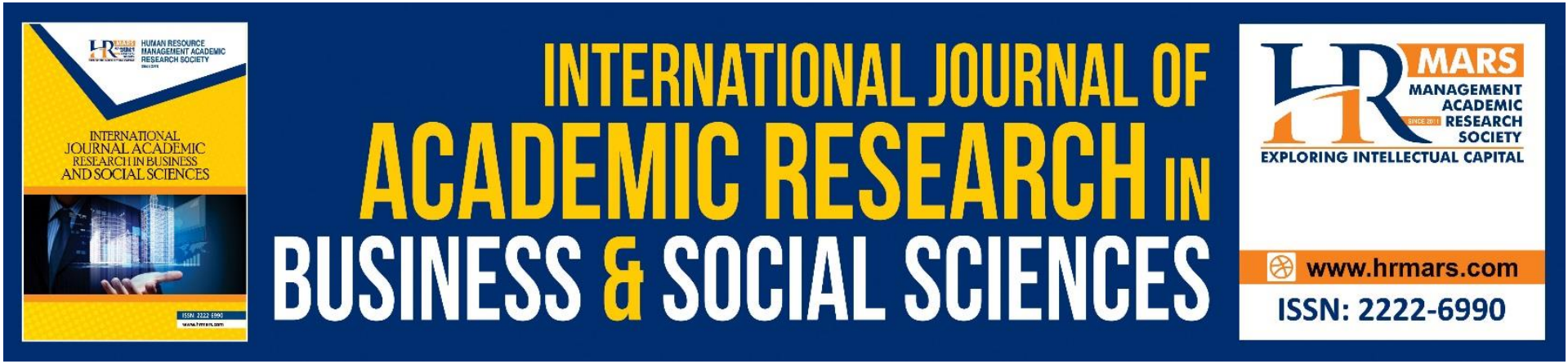

\title{
Entrepreneurial Interest as an Antecedent of Entrepreneurial Event Model and Agropreneurial Intention
}

\section{Sylvia Nabila Azwa Ambad}

To Link this Article: http://dx.doi.org/10.6007/IJARBSS/v12-i1/11849

DOI:10.6007/IJARBSS/v12-i1/11849

Received: 12 November 2021, Revised: 18 December 2021, Accepted: 27 December 2021

Published Online: 09 January 2022

In-Text Citation: (Ambad, 2022)

To Cite this Article: Ambad, S. N. A. (2022). Entrepreneurial Interest as an Antecedent of Entrepreneurial Event Model and Agropreneurial Intention. International Journal of Academic Research in Business and Social Sciences, 12(1), 173-186.

Copyright: @ 2022 The Author(s)

Published by Human Resource Management Academic Research Society (www.hrmars.com) This article is published under the Creative Commons Attribution (CC BY 4.0) license. Anyone may reproduce, distribute, translate and create derivative works of this article (for both commercial and non0-commercial purposes), subject to full attribution to the original publication and authors. The full terms of this license may be seen at: http://creativecommons.org/licences/by/4.0/legalcode

Vol. 12, No. 1, 2022, Pg. $173-186$

Full Terms \& Conditions of access and use can be found at http://hrmars.com/index.php/pages/detail/publication-ethics 


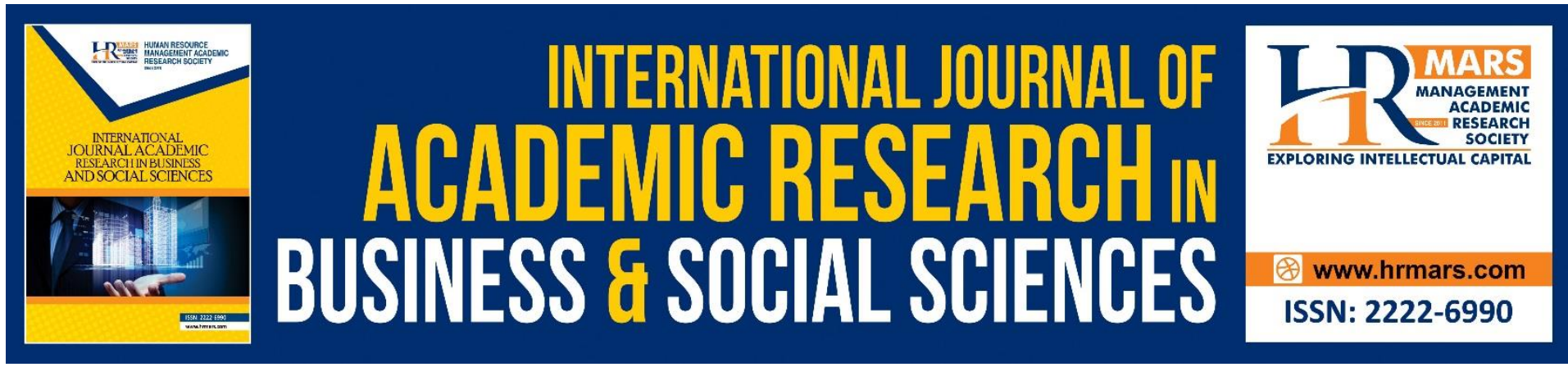

\title{
Entrepreneurial Interest as an Antecedent of Entrepreneurial Event Model and Agropreneurial Intention
}

\section{Sylvia Nabila Azwa Ambad}

Faculty of Business and Management, Universiti Teknologi MARA, Cawangan Sabah, 88997 Kampus Kota Kinabalu, Sabah, Malaysia; Arshad Ayub Graduate Business School, Universiti Teknologi MARA, 40000 Shah Alam, Selangor, Malaysia.

Email: nabila1793@uitm.edu.my

\begin{abstract}
The Malaysian government has been perpetually encouraging the involvement of youths in agricultural entrepreneurship. Various schemes and programmes have been initiated to attract youths to venture into agropreneurship. Unfortunately, youth participation in agriculture is still low. Thus, this study aims to investigate the agropreneurial intention among youth in Malaysia using the entrepreneurial event model (EEM) and enterprising interest. An online survey was conducted among 353 youth across Malaysia, and data collected were analysed using SmartPLS 3.3.3. Consistent with the theory, all hypotheses are found to be significant. First, the findings confirmed that enterprising interest is an antecedent of perceived desirability and feasibility, while all three dimensions of EEM positively affect agropreneurial intention. Additionally, perceived desirability and feasibility mediate the relationship between enterprising interest and agropreneurial intention. This study contributes to the scarce literature on agropreneurship, especially in the Malaysian context. Keywords: Entrepreneurial Event Model, Perceived Desirability, Perceived Feasibility, Propensity to Act, Agropreneurship, Entrepreneurial Intention
\end{abstract}

\section{Introduction}

Agricultural entrepreneurship or agropreneurship has gained popularity due to its significant contribution to maintaining food security and increasing productivity and innovation. Besides, agropreneurship is seen as an essential means of assisting the rural population in overcoming poverty. Agricultural activities' effectiveness in combating poverty and unemployment is evidenced by several successful high-impact agricultural programmes initiated by the Ministry of Agriculture and Food Industries (MAFI). Additionally, agriculture investment is more effective in alleviating poverty, especially among the poorest people, than investment in nonagricultural sectors (Fao, 2017). It also improves the nation's food self-sufficiency level (SSL) and reduces over-reliance on imported food.

However, despite numerous efforts taken to elevate the agricultural sector, it faces many issues, such as poor participation of youths. The agricultural population is ageing globally, with the average age being 50 years and above (Musa, 2020). The younger generation is less 
likely to choose farm entrepreneurship as a career than other industries (Pindado \& Sánchez, 2017). Youth disregard agropreneurship as a career because they perceive it as low socioeconomic status, dirty, risky, demands hard work, and fits only for the less educated and unemployed (Musa et al., 2021).

The future generation must be motivated to participate in the modern agricultural industry to boost the global food supply and address food security issues. Younger farmers are more productive and achieve higher profitability (Hamilton et al., 2015; Zagata \& Sutherland et al., 2015). In addition, they are more versatile, adaptive, inclined to adopt technology, and tend to promote diverse agricultural activities (Morris et al., 2017). Thus, investigating youth agropreneurship intentions would provide crucial insights into nurturing more agropreneurs to policymakers and scholars. This would be advantageous in developing countries, in which, despite the agriculture growth, youth involvement in this sector is disturbingly scarce. We urgently need to groom more farmers' successors to ensure agriculture sector viability and continuity.

There are minimal empirical studies on the role of agricultural entrepreneurship, especially in Malaysia. However, a recent increase in relevant studies shows that entrepreneurship has the potential to reduce poverty and conflict in developing countries (Bruton et al., 2013; Tobias \& Barbosa-Leiker, 2013). The objectives of this study are;

i) to identify the antecedent effect of enterprising interest on EEM;

ii)to examine the effect of EEM the agropreneurial intention among youth, and;

iii) to determine the mediating role of perceived desirability and feasibility in the relationship between enterprising interest and agropreneurial intention.

This study was conducted among youths in Malaysia with ages ranging between 18 and 40 . The findings of this study will greatly contribute to a few areas, proposing the strategy to increase the participation of youth in agriculture that is useful for policymakers and higher learning institutions.

\section{Literature Review}

\section{Agropreneurial Intention}

Agricultural entrepreneurship has been called and defined with various terms, such as farm entrepreneurship and agropreneurship(Dias et al., 2018). For this study, the term agropreneurship represents agricultural entrepreneurs who are owner-managers of agriculture-based businesses. The businesses constitute both farm and non-farm activities undertaken by individuals for profitable gain. The farming activities include soil cultivation, crop growing, livestock rearing, and other agriculture-related activities (Naminse \& Zhuang, 2018).

Recognising individuals' entrepreneurial intentions is vital in the development of more entrepreneurs. The earlier stage of entrepreneurship is the formation of entrepreneurial intention (Hisrich et al., 2013). Entrepreneurship is a conscious and anticipated behaviour (Krueger et al., 2000). Therefore, the entrepreneurial intention is assumed to precede any entrepreneurial act and serve as a reliable predictor of entrepreneurship. Individuals will only venture into entrepreneurship if they show a sufficient level of intent for entrepreneurship. Therefore, studying entrepreneurial intention is beneficial because it is a reliable predictor of entrepreneurial behaviour, although measuring actual entrepreneurial behaviour is difficult (Wu, 2010). In this study context, agropreneurial intention refers to the willingness of an individual to participate in agropreneurship in the future. 


\section{Entrepreneurial Event Model (EEM)}

EEM was among the earliest framework developed by Shapero and Sokol (1982) to predict entrepreneurial intention. Many scholars used EEM to determine the intention for various types of entrepreneurship; for example, social entrepreneurial intention by Mair and Noboa (2006). As presented in Figure 1, EEM consists of three dimensions: perceived feasibility, perceived desirability, and propensity to act that influence the intention (Shapero \& Sokol, 1982). The intention is a solid predictor of an individual's future behaviour to start a venture. Souitaris et al (2007) revealed that the correlations between intention and actual behaviour were relatively strong, ranging from 0.51 to 0.71 .

According to Shapero (1984), the underlying mechanisms of the EEM are more complicated than they appeared to be. In some circumstances, both perceived feasibility and perceived desirability were enough to predict the entrepreneurial intention; however, others studies indicated that all three variables might account for the variance explained. In this study, all three dimensions of EEM are employed.

Perceived desirability refers to an individual's belief that the notion of beginning a business is attractive. The degree to which individuals believe they are personally capable of starting their own firm and regard the option of becoming an entrepreneur to be realistic is referred to as perceived feasibility. The propensity to act on opportunities refers to a person's willingness to follow through on a decision (Shapero \& Sokol, 1982). Furthermore, it is based on an individual's sense of control by adopting appropriate actions to achieve the intended results (Krueger et al., 2000).

Figure 1: Entrepreneurial Event Model

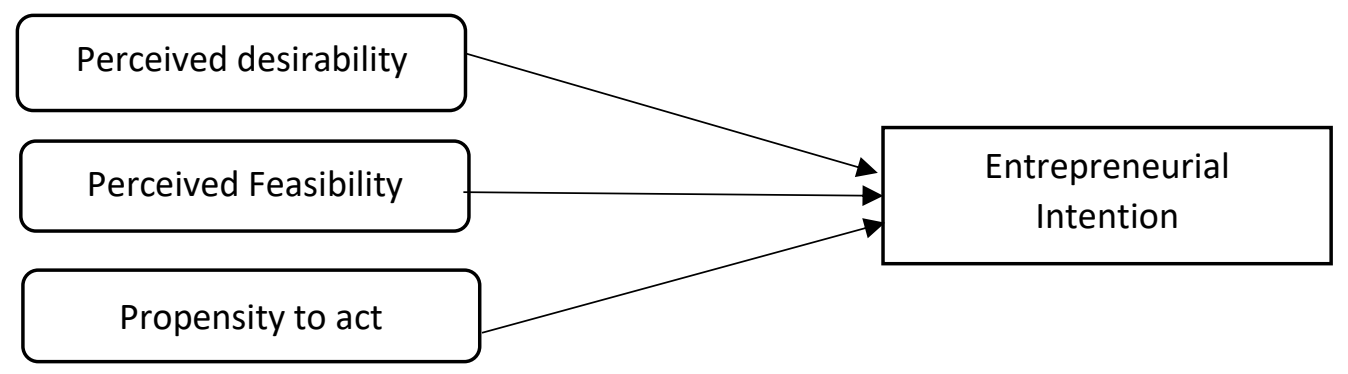

\section{Effects of EEM on Agropreneurial Intention}

In EEM, the entrepreneurial intentions will be higher when the individual sees entrepreneurship as an appealing and feasible career choice (Shapero \& Sokol, 1982). EEM was able to explain more than half of the variance in entrepreneurial intention (Krueger, 1993). Perceived desirability, feasibility, and propensity to act are crucial to entrepreneurial intents (Krueger et al., 2000; Fitzsimmons \& Douglas 2011; Otache et al., 2021). Similarly, there was a shred of empirical evidence that EEM predicted agropreneurial intention among agriculture students in Malaysian universities (Yusoff et al., 2016).

Perceived desirability functions as the motivational factor; the attractiveness of starting one's own business leads to the intention to launch a venture. In the context of agropreneurship, perceived desirability is the degree to which individuals find the possibility of starting an agropreneurship business to be attractive. Meanwhile, perceived feasibility refers to individuals' perception that starting a new business related to agriculture is achievable in 
future states. Individuals with low perceived desirability and feasibility will encounter difficulties running their agriculture-based business that is challenging and uncertain due to climate change, filth, exhaustion, high failure, and uncertain income.

In the agropreneurship context, the propensity to act as a personal tendency to behave based on one's own decisions refers to the decision to pursue agropreneurship. It is highly recommended to include the propensity to act dimension in EEM since it is hard to shape an "intention" without it (Krueger et al., 2000). Propensity to act is translated into the internal locus of control instead of relying on fundamental causes such as luck; effective entrepreneurs take responsibility for their success or failure (Fagbohungbe \& Jayeoba, 2012). Recent studies conducted among business students of public universities in Pakistan found that both perceived desirability and feasibility positively affected entrepreneurial intention (Soomro et al., 2020). By nature, business students are probably better at executing entrepreneurial activities based on their syllabus. This could have occurred because of their high level of confidence, awareness, or understanding of entrepreneurship and its effects. Similarly, a study conducted among private university students in Malaysia discovered that both perceived desirability and feasibility predicted entrepreneurial intention (Ahmad et al., 2019).

Another recent study conducted among business and management universities students in Vietnam indicated that all three dimensions of EEM positively affected entrepreneurial intention (Bui et al., 2020). Moreover, perceived desirability has the strongest effect on entrepreneurial intention. The findings demonstrate that the ambition to start a business or the desire to become an entrepreneur has the greatest influence on students' job choices. In the same vein, a study among the agri-food industry operators in Pakistan confirmed that perceived feasibility was the strongest predictor of entrepreneurial intention (Yaseen et al., 2018). This might be due to the government's strong support to entrepreneurs towards adapting to the hostile and dynamic business environment. Among the support provided were incentives and credit facilities on easy terms, leading to agropreneurs finding that agropreneurship is feasible. Thus, the following hypotheses are proposed.

$\mathrm{H} 1$ : Perceived desirability is positively affected agropreneurial intentions.

$\mathrm{H} 2$ : Perceived feasibility is positively affected agropreneurial intentions.

H3: Propensity to act is positively affected agropreneurial intentions.

\section{Effects of Enterprising Interest on Perceived Desirability and Perceived Feasibility}

According to Holland's RIASEC theory, people are motivated to pursue a job that involves employment tasks that they find naturally enjoyable and intriguing (Holland, 1997). This leads to the use of enterprising interest in RIASEC as an antecedent of EEM in this study. Holland's divided the work activities preferences or vocational interests into six types: Realistic, Investigative, Artistic, Social, Enterprising, and Conventional (RIASEC). Since individuals with an enterprising interest are more likely to choose entrepreneurship as a career, it would most likely predict agropreneurial intention.

One of the most fundamental characteristics of entrepreneurship is the entrepreneurial mindset (Liu et al., 2020) that motivates individuals to be involved in entrepreneurship (Martínez-González \& Kobylińska, 2019). According to Holland's theory, those characterised as persuaders or having entrepreneurial interests are more interested in positions that require them to lead, influence, and persuade others. Additionally, they enjoy a certain amount of risk in their work. Thus, a person with an enterprising interest is most likely to 
become an entrepreneur because the working environment fits their personality and interest. Holland's RIASEC theory suggests that individuals with enterprising interests perceived the entrepreneurial career as desirable and feasible. A study by Almeida et al. (2014) revealed that the enterprising dimension of the RIASEC displayed the highest correlations with entrepreneurial tendencies and abilities. Thus, the following hypotheses are proposed.

H4: Enterprising interest has a positive effect on perceived desirability.

H5: Enterprising interest has a positive effect on perceived feasibility.

Mediating effect of Enterprising Interest on Perceived Desirability and Perceived Feasibility. In previous studies, perceived desirability and feasibility were widely used as mediating variables in determining entrepreneurial intention (e.g., Saeed et al., 2014; Tan et al.,2021). Empirical evidence has consistently revealed the mediating role of perceived desirability and feasibility. In a recent study by Tan et al. (2021), both perceived desirability and perceived feasibility mediate the relationship between personality traits and social entrepreneurial intention among 503 individuals in Vietnam. Similarly, a study in Greek universities found that perceived desirability mediated the relationship between student creativity, proactivity, and entrepreneurial intention (Zampetakis, 2008). Likewise, both perceived desirability and feasibility mediated the relationship between family business background and entrepreneurial intention among university students in Pakistan (Saeed et al., 2014). Therefore, this study expects that enterprising interest influences both perceived desirability and feasibility, positively affecting agropreneurial intention. This notion is reflected in the following hypotheses:

H6: Perceived desirability positively mediates the relationship between enterprising interest and agropreneurial intention.

H7: Perceived feasibility positively mediates the relationship between enterprising interest and agropreneurial intention.

\section{Methods}

\section{Participants and Procedure}

This study used judgemental sampling, whereby only youth aged between 18 to 30 years old were selected. Participants completed the survey online through a Google Form broadcasted via social media sites, e-mail, and other online platforms. First, participants answered their demographic information followed by EEM, enterprising interest, and agropreneurial intention. A total of 353 youth participated in this study, whereby $97(27.5 \%)$ were males, and $256(72.5 \%)$ were female. Most of the participants were 18 to 20 years old (55\%), followed by 21 to 23 years old (34.3\%). In terms of the highest educational level attained, the majority of the respondents have a Diploma (53.8\%), followed by secondary school education $(26.3 \%)$, Bachelor's Degree (18.1\%), and Master's Degree (1.7\%).

\section{Measures}

All items for perceived desirability and feasibility were adopted and modified from Krueger's (1993) to measure the degree of desirability and feasibility. Items for the propensity to act were adopted from Lee and Tsang (2001). Meanwhile, items for enterprising interest were adapted from Holland Code (RIASEC) Test. Finally, for dependent variable scales, the 
agropreneurial measures were adopted and modified from Elfving et al. (2017). All items were measured using a 5-point Likert scale, ranging from 'strongly disagree' to 'strongly agree'.

\section{Data Analysis and Results}

Data collected were analysed using SmartPLS 3.3.3 (Ringle et al., 2015). One reason to use partial least squares modeling (SEM-PLS) is the non-normal data distribution. The normality was assessed using the multivariate skewness and kurtosis suggested by Hair et al. (2017). The result indicates that data collected in this study was not multivariate normal, Mardia's multivariate skewness $(\beta=3.082, p<0.01)$ and Mardia's multivariate kurtosis $(\beta=42.964, p<$ $0.01)$. Thus, the non-parametric bootstrap procedure using SEM-PLS is appropriate. The SmartPLS analysis constituted two steps: measurement model assessments and structural model assessments.

\section{Measurement Model}

In the first step, the validity and reliability of the instruments were assessed before hypotheses testing. The measurement model was assessed using loadings, the composite reliability (CR), and the average variance extracted (AVE). The threshold for loadings should be $\geq 0.5$, the $A V E \geq 0.5$, and the $C R \geq 0.7$. As shown in Table 1, the AVEs are all higher than 0.5, and the CRs are all higher than 0.7. The loadings were also acceptable, and none were deleted, with only two loadings scored less than 0.708 (Hair et el., 2019).

The HTMT criterion was used for the discriminant validity as suggested by (Franke and Sarstedt, 2019). As shown in Table 2, the values of HTMT were all lower than the criterion of $\leq 0.85$; as such, it can be determined that the respondents recognised that the five constructs are distinct. Therefore, all items used in this study are valid and reliable. 
Table 1

Measurement Model

\begin{tabular}{|c|c|c|c|c|}
\hline First Order Constructs & Items & Loadings & CR & AVE \\
\hline \multirow[t]{3}{*}{ Perceived Desirability (PD) } & PD1 & 0.726 & \multirow[t]{3}{*}{0.794} & \multirow[t]{3}{*}{0.562} \\
\hline & PD2 & 0.747 & & \\
\hline & PD3 & 0.776 & & \\
\hline \multirow[t]{5}{*}{ Perceived Feasibility (PF) } & PF1 & 0.828 & \multirow[t]{3}{*}{0.926} & \multirow[t]{3}{*}{0.715} \\
\hline & PF2 & 0.876 & & \\
\hline & PF3 & 0.797 & & \\
\hline & PF4 & 0.868 & & \\
\hline & PF5 & 0.856 & & \\
\hline \multirow[t]{3}{*}{ Propensity to Act (PA) } & PA1 & 0.739 & \multirow[t]{3}{*}{0.815} & \multirow[t]{3}{*}{0.596} \\
\hline & PA2 & 0.756 & & \\
\hline & PA3 & 0.819 & & \\
\hline \multirow[t]{7}{*}{ Enterprising Interest (EN) } & EN1 & 0.764 & \multirow[t]{4}{*}{0.897} & \multirow[t]{4}{*}{0.555} \\
\hline & EN2 & 0.705 & & \\
\hline & EN3 & 0.698 & & \\
\hline & EN4 & 0.784 & & \\
\hline & EN5 & 0.747 & & \\
\hline & EN6 & 0.785 & & \\
\hline & EN7 & 0.723 & & \\
\hline \multirow[t]{3}{*}{ Agropreneurial Intention (Al) } & Al1 & 0.836 & \multirow[t]{3}{*}{0.875} & \multirow[t]{3}{*}{0.699} \\
\hline & $\mathrm{Al} 2$ & 0.862 & & \\
\hline & Al3 & 0.810 & & \\
\hline
\end{tabular}

Table 2

Discriminant Validity (HTMT)

\begin{tabular}{|l|c|c|c|c|c|}
\hline & 1 & 2 & 3 & 4 & 5 \\
\hline 1. Agropreneurial Intention (AI) & & & & & \\
\hline 2. Enterprising (EN) & 0.498 & & & & \\
\hline 3. Propensity to act (PA) & 0.470 & 0.727 & & & \\
\hline 4. Perceived Desirability (PD) & 0.604 & 0.822 & 0.701 & & \\
\hline 5. Perceived Desirability (PF) & 0.422 & 0.473 & 0.319 & 0.761 & \\
\hline
\end{tabular}

\section{Structural Model}

The second stage following the measurement model assessment is the structural model assessment. The effect of the three predictors (EEM dimensions) on agropreneurial intention was assessed; the $R^{2}$ was $0.266\left(Q^{2}=0.163\right)$, suggesting that EEM explained $26.6 \%$ of the variance in agropreneurial intention. As shown in Table 3, the direct hypotheses for perceived desirability $(B=0.251, p<0.01)$, perceived feasibility $(B=0.178, p<0.01)$ and propensity to act $(B=0.220, p<0.01$ ) are all positively related to agropreneurial intention. Thus, $\mathrm{H} 1, \mathrm{H} 2$, and H3 are supported. The $95 \%$ confidence intervals bias-adjusted did not show any intervals straddling a 0 , validating the findings. 
In terms of antecedent effects of enterprising interest on perceived desirability and feasibility, enterprising interest has a positive effect on perceived desirability $(\theta=0.632, p<0.01)$ and perceived feasibility $(B=0.438, p<0.01)$. Thus, $\mathrm{H} 4$ and $\mathrm{H} 5$ are supported. Among all predictors, enterprising interest strongly affects perceived desirability $\left(f^{2}=665\right)$ and perceived feasibility $\left(f^{2}=0.238\right)$. Enterprising interest explains $39.9 \%\left(Q^{2}=0.209\right)$ of the variance in perceived desirability and $19.9 \%\left(Q^{2}=0.128\right)$ in perceived feasibility.

Next, the indirect hypothesis or mediating effect results are presented in Table 4, following the suggestions of Preacher and Hayes (2008). Both hypotheses were significant. In other words, perceived desirability $(\beta=0.632, p<0.01)$ and perceived feasibility $(\theta=0.438, p<0.01)$ positively mediated the relationship between enterprising interest and agropreneurial intention. Thus, $\mathrm{H} 6$ and $\mathrm{H} 7$ are also supported.

Table 3

Hypothesis Testing Direct Effects

\begin{tabular}{|l|l|r|r|r|r|r|r|c|c|c|}
\hline \multicolumn{2}{|l|}{ Hypotheses } & Std Beta & Std Error & t-value & $\mathbf{p}$-value & $\mathbf{B C I}$ LL & $\mathbf{B C I}$ UL & $\mathbf{f}^{\mathbf{2}}$ & VIF & Decision \\
\hline $\mathrm{H} 1$ & PD $\rightarrow$ Al & 0.251 & 0.067 & 3.752 & 0.000 & 0.144 & 0.363 & 0.052 & 1.672 & Supported \\
\hline H2 & PF $\rightarrow$ Al & 0.178 & 0.058 & 3.058 & 0.001 & 0.081 & 0.273 & 0.030 & 1.435 & Supported \\
\hline H3 & PA $\rightarrow$ Al & 0.220 & 0.054 & 4.097 & 0.000 & 0.127 & 0.300 & 0.052 & 1.274 & Supported \\
\hline H4 & EN $\rightarrow$ PD & 0.632 & 0.030 & 20.773 & 0.000 & 0.573 & 0.675 & 0.665 & 1.000 & Supported \\
\hline H5 & EN $\rightarrow$ PF & 0.438 & 0.046 & 9.524 & 0.000 & 0.356 & 0.509 & 0.238 & 1.000 & Supported \\
\hline
\end{tabular}

Note: We use a $95 \%$ confidence interval with a bootstrapping of 5,000

Table 4

Hypothesis Testing Indirect Effects

\begin{tabular}{|l|l|c|c|c|c|c|c|c|}
\hline \multicolumn{2}{|l|}{ Hypotheses } & Std Beta & Std Error & t-values & p-values & $\begin{array}{c}\text { BCl } \\
\text { LL }\end{array}$ & $\begin{array}{c}\text { BCl } \\
\text { UL }\end{array}$ & Decision \\
\hline H6 & EN $\rightarrow$ PD $\rightarrow$ Al & 0.159 & 0.044 & 3.610 & 0.000 & 0.089 & 0.232 & Supported \\
\hline H7 & EN $\rightarrow$ PF $\rightarrow$ Al & 0.078 & 0.027 & 2.838 & 0.002 & 0.036 & 0.125 & Supported \\
\hline
\end{tabular}

Note: We use a $95 \%$ confidence interval with a bootstrapping of 5,000 
Figure 2: Research Model with Results

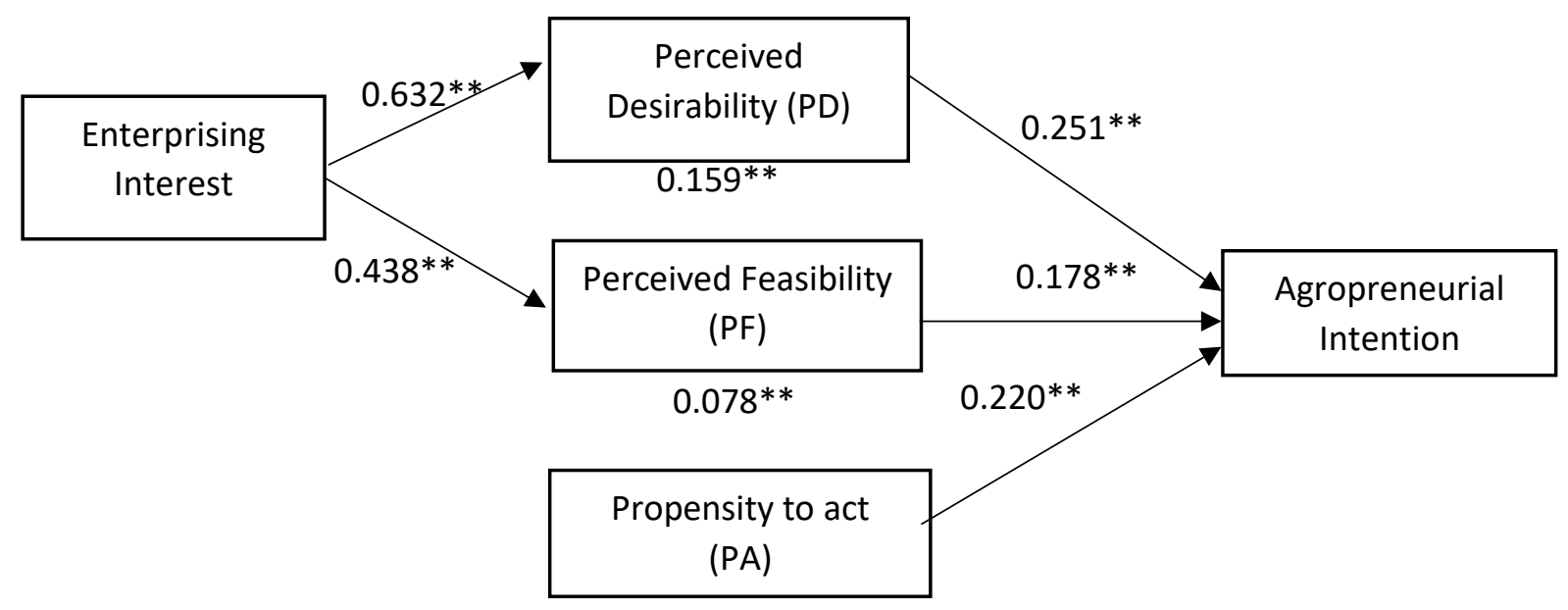

Notes: Significant at $* * p<0.01$

\section{Discussion}

This study's findings reveal several key discoveries that add to the body of knowledge, particularly on agropreneurial intention, and propose some practical contributions. The study confirms the applicability of the integration of the EEM and enterprising interest in explaining agropreneurial intention. The study explains that youth intention to be involved in agropreneurship derives from the perception that setting up an agro-based business is desirable, feasible, and willing to act. These findings are consistent with the previous studies (Ahmad et al., 2019; Bui et al.,2020; Soomro et al., 2020; Yaseen et al., 2018; Yusoff, 2016).

Furthermore, the results show that enterprising interest positively affects both perceived desirability and feasibility. This is in line with Holland's Theory that a person who scores higher on the enterprising element is motivated to be involved in entrepreneurship because it is congruent with their personality and interest. Besides, this study supports the theory, stating that enterprising interest leads to the perception that starting an agropreneurship is attractive and attainable.

Perceived desirability and feasibility are also shown to be mediators in the relationship between enterprising interest and agropreneurial intention. This is consistent with other studies that proposed EEM as a mediator (Saeed et al., 2014; Tan et al., 2021; Zamptekis, 2008). Individuals with enterprising interests will choose a career in which they can lead, influence, persuade, and manage people for economic gain. Thus, being an agropreneur is rewarding for them.

\section{Practical Contribution}

As a practical contribution, this study proposes that the government and its agencies attempting to groom future agropreneurs should consider conducting the Holland Code (RIASEC) Test to identify and select the right candidate for their programmes. Holland asserts that individuals working in an environment that fits and rewards their type are more likely to be successful and satisfied. Thus, choosing the right candidates will ensure the resources are used efficiently and effectively. 
Lastly, the effort to promote agriculture as a viable, desirable, and feasible industry should be intensified. Evidently, this study shows that EEM's dimensions of perceived desirable, feasibility, and propensity to act positively affect the agropreneurial intention. This country urgently needs to groom more farmers' successors to ensure agriculture sector viability and continuity.

\section{Limitation and Future Research Suggestion}

This study, like many other studies, has limitations. First, although the utilisation of EEM and enterprising interest offers substantial variance explained $\left(R^{2}=26.6 \%\right)$, further research should integrate other theories, such as the theory of planned behavior, entrepreneurial tendencies, and abilities (META, entrepreneurial attitude orientation, and social cognitive theory). This will ensure more robust findings and contribute more to the literature. Second, although intention and actual behaviour are highly correlated, cross-sectional has its limitations, especially on the changes in attitude and intention over time. Thus, a longitudinal study is needed to enrich the current findings. Third, in terms of respondents, since this study aims to identify the determinant of agropreneurial intention, future studies should choose youth with agricultural studies backgrounds.

\section{Conclusion}

Although the agriculture sector only contributed about 7.3\% of Malaysia's GDP in 2018, the agricultural sector has been the backbone of the Malaysian economy for many years, supplying agricultural products for domestic consumption, providing employment, and reducing poverty in the rural areas. Furthermore, the agriculture sector continues to be the backbone of the local rural economies. During the 1997/1998 financial crisis that badly hit Asian economies, the agricultural exports saved Malaysia's balance of payment due to the high price of palm oil (Fauzana, 2006). Given the current global economic condition, the agricultural sector may help to revive the economy yet again. Therefore, youth participation in the agricultural sector is timely to help boost productivity and, in turn, ensure food security, avoid food crisis, reduce poverty in rural areas, and lessen the dependency on imported food. Meanwhile, the government should continue promoting agropreneurship to youth by providing a conducive agropreneurship ecosystem, such as widening market access, modernising the infrastructure, increasing technology use, and providing more schemes and grants. These will increase the perceived desirability and feasibility of the agropreneurship.

\section{Acknowledgement}

This work was supported by the FRGS-RACER grant (Ref: RACER/1/2019/SS03/UITM//3), Ministry of Education, Malaysia.

\section{References}

Ahmad, N. H., Ramayah, T., Mahmud, I., Musa, M., \& Anika, J. J. (2019). Entrepreneurship as a preferred career option. Education + Training, 61(9), 1151-1169. doi:10.1108/et-122018-0269

Almeida, P. I., Ahmetoglu, G., \& Chamorro-Premuzic, T. (2014). Who wants to be an entrepreneur? The relationship between vocational interests and individual differences in entrepreneurship. Journal of Career Assessment, 22(1), 102-112.

Bruton, G. D., Ketchen, D. J., \& Ireland, R. D. (2013). Entrepreneurship as a solution to poverty. Journal of Business Venturing, 28(6), 683- 
689.https://doi.org/10.1016/j.jbusvent.2013.05.002

Bui, T. H. V., Nguyen, T. L. T., Tran, M. D., \& Nguyen, T. A. T. (2020). Determinants influencing entrepreneurial intention among undergraduates in universities of Vietnam. The Journal of Asian Finance, Economics, and Business, 7(7), 369-378.

Dias, C. S. L., Rodrigues, R. G., \& Ferreira, J. J. (2018). What's new in the research on agricultural entrepreneurship? Journal of Rural Studies, 65(November), 99-115.

Elfving, J., Brännback, M., \& Carsrud, A. (2017). Motivations matter in entrepreneurial behavior: Depends on the context. In Revisiting the Entrepreneurial Mind (pp. 211-217). Springer, Cham.

Fagbohungbe, O. B., \& Jayeoba, F. I. (2012). Locus of Control, Gender and Entrepreneurial Ability. British Journal of Arts \& Social Sciences, 11(1), 74-85.

FAO. (2017). Ending poverty and hunger by investing in agriculture and rural areas. Food and Agriculture Organization of the United Nations. Sustainable Development Goals.

Fitzsimmons, J. R., \& Douglas, E. J. (2011). Interaction between feasibility and desirability in the formation of entrepreneurial intentions. Journal of business venturing, 26(4), 431440.

Hair, J. F., Thomas, G., Hult, M., Ringle, C. M., \& Sarstedt, M. (2017). A Primer on Partial Least Squares Structural Equation Modeling (2nd ed.). Thousand Oakes, CA: Sage.

Hair, J., Risher, J., Sarstedt, M.,\& Ringle, C. (2019), When to use and how to report the results of PLS-SEM. European Business Review, 31(1), 2-24.

Hamilton, W., Bosworth, G., \& Ruto, E. (2015). Entrepreneurial younger farmers and the "young farmer problem" in England. Agriculture \& Forestry, vol. 61(4), pp. 61-69.

Hisrich, R. D., Peters, M. P., \& Shepherd, D. A. (2013). Entrepreneurship (9th ed.). New York: McGraw Hil

Holland, J. L. (1997). Making vocational choices: A theory of vocational personalities and work environments. Psychological Assessment Resources.

Krueger, N. (1993). The impact of prior entrepreneurial exposure on perceptions of new venture feasibility and desirability. Entrepreneurship theory and practice, 18(1), 5-21.

Krueger, N. F., Reily, M. D., Carsrud, A. (2000). Competing models of entrepreneurial intention. Journal of Business Venture, 15, 411-432

Krueger, N. F. (2000). The cognitive infrastructure of opportunity emergence. Entrepreneurship Theory and

Lee, D. Y., \& Tsang, E. W. (2001). The effects of entrepreneurial personality, background and network activities on venture growth. Journal of management studies, 38(4), 583-602.

Liu, T., Walley, K., Pugh, G., \& Adkins, P. (2020). Entrepreneurship education in China: Evidence from a preliminary scoping study of enterprising tendency in Chinese university students. Journal of Entrepreneurship in Emerging Economies.

Mair, J., \& Noboa, E. (2006). Social entrepreneurship: How intentions to create a social venture are formed. In Social entrepreneurship (pp. 121-135). Palgrave Macmillan, London.

Mair, J., \& Noboa, E. (2006). Social entrepreneurship: How intentions to create a social venture are formed. In Social entrepreneurship (pp. 121-135). Palgrave Macmillan, London.

Martínez-González, J. A., \& Kobylińska, U. (2019). Influence of personal variables on entrepreneurial intention: a comparative study between Poland and Spain. Engineering Management in Production and Services, 11(1). 
Musa, S. F. P. D. (2020). A study on youths' aspirations and perceptions of agriculture and its policy implications. In J. Andrei (Ed.), Agricultural policy, rural development, and entrepreneurship in contemporary economies. IGI-Global

Musa, S. F. P. D., Idris, D. S. R. P. H., \& Haris, N. B. M. (2021). Investigating Agropreneurial Intention among Students in Higher Learning Institution using the Theory of Planned Behaviour. Pertanika Journal of Social Sciences \& Humanities, 29(2).

Naminse, E. Y., \& Zhuang, J. (2018). Does farmer entrepreneurship alleviate rural poverty in China? Evidence from guangxi province. PLOS ONE, 13(3), 1-18.

Otache, I., Edopkolor, J. E., \& Okolie, U. C. (2021). Entrepreneurial self-confidence, perceived desirability and feasibility of hospitality business and entrepreneurial intentions of hospitality management technology students. The International Journal of Management Education, 19(2), 100507. Practice, 24(3), 5-23.

Preacher, K. J., \& Hayes, A. F. (2008). Asymptotic and resampling strategies for assessing and comparing indirect effects in multiple mediator models. Behavior research methods, 40(3), 879-891.

Ringle, C. M., Wende, S., \& Becker, J.-M. (2015). "SmartPLS 3." Boenningstedt: SmartPLS $\mathrm{GmbH}$.

Saeed, S., Muffatto, M., \& Yousafzai, S. Y. (2014). Exploring intergenerational influence on entrepreneurial intention: the mediating role of perceived desirability and perceived feasibility. International Journal of Entrepreneurship and Innovation Management, 18(2-3), 134-153.

Shapero, A., \& Sokol, L. (1982). Social dimensions of entrepreneurship. In C.A. Kent, D.L. Sexton, \& K.H.

Shapero, A., \& Sokol, L. (1982). The Social Dimensions of Entrepreneurship. In C.A. Kent, D.L. Sexton, \& K.H. Vesper (Eds.). Encyclopedia of Entrepreneurship. Englewood Cliffs, NJ: Prentice-Hall, 72-90.

Shapero, A. (1984). The Entrepreneurial Event,In: C. A. Kent Ed., The environment for entrepreneurship, M.A.: Lexington Books, Toronto, 1984, pp. 21-40.

Soomro, B. A., Lakhan, G. R., Mangi, S., \& Shah, N. (2020). Predicting entrepreneurial intention among business students of public sector universities of Pakistan: an application of the entrepreneurial event model. World Journal of Entrepreneurship, Management and Sustainable Development.

Souitaris, V., Zerbinati, S., \& Al-Laham, A. (2007), "Do entrepreneurship programmes raise entrepreneurial intention of science and engineering students? The effect of learning, inspiration and resources", Journal of Business Venturing, Vol. 22 No. 4, pp. 566-591.

Tan, L. P., Pham, L. X., \& Bui, T. T. (2021). Personality traits and social entrepreneurial intention: the mediating effect of perceived desirability and perceived feasibility. The Journal of Entrepreneurship, 30(1), 56-80.

Tobias, J. M., Mair, J., \& Barbosa-Leiker, C. (2013). Toward a theory of transformative entrepreneuring: Poverty reduction and conflict resolution in Rwanda's entrepreneurial coffee sector. Journal of Business Venturing, 28(6), 728-742. https://doi.org/10.1016/j.jbusvent.2013.03.003

Vesper (Eds.), The encyclopedia of entrepreneurship (pp. 72-90). Englewood Cliffs, NJ: Prentice-Hall.

$\mathrm{Wu}$, J. (2010). The impact of corporate supplier diversity programs on corporate purchasers' intention to purchase from women-owned enterprises: An empirical test. Business \& Society, 49(2), 359-380 
Yaseen, A., Saleem, M. A., Zahra, S., \& Israr, M. (2018). Precursory effects on entrepreneurial behaviour in the agri-food industry. Journal of Entrepreneurship in Emerging Economies.

Yusoff, A., Ahmad, N. H., \& Halim, H. A. (2016). Tailoring future agropreneurs: The impact of academic institutional variables on entrepreneurial drive and intentions. Journal of Entrepreneurship Education, 19(2), 156.

Zagata, L., \& Sutherland, L. (2015). Deconstructing the 'young farmer problem in Europe': Towards a research agenda. Journal of Rural Studies, vol. 38, pp. 39-51.

Zampetakis, L., Anagnosti, A., \& Anagnosti, A. (2014), Understanding entrepreneurial intentions of students in agriculture and related sciences, Poster paper prepared for presentation at the EAAE 2014 Congress' Agri-Food and Rural Innovations for Healthier Societies', Ljubljana, August 26-29. 